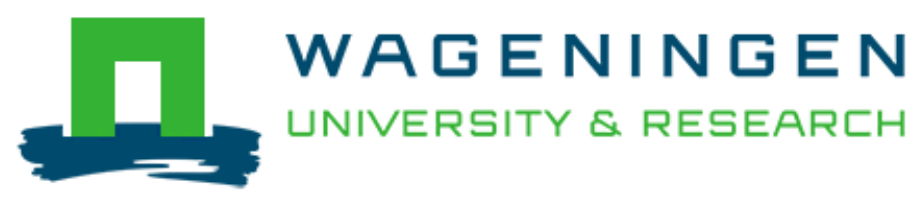

In vitro detection of cardiotoxins or neurotoxins affecting ion channels or pumps using beating cardiomyocytes as alternative for animal testing

Nicolas, J. A. Y., Hendriksen, P. J. M., de Haan, L. H. J., Koning, R., Rietjens, I. M. C. M., \& Bovee, T. F. H.

This is a "Post-Print" accepted manuscript, which has been published in "Toxicology in Vitro"

This version is distributed under a non-commercial no derivatives Creative Commons (C) $(1) \Theta$ reproduction in any medium, provided the original work is properly cited and not used for commercial purposes. Further, the restriction applies that if you remix, transform, or build upon the material, you may not distribute the modified material.

Please cite this publication as follows:

Nicolas, J. A. Y., Hendriksen, P. J. M., de Haan, L. H. J., Koning, R., Rietjens, I. M. C. M., \& Bovee, T. F. H. (2015). In vitro detection of cardiotoxins or neurotoxins affecting ion channels or pumps using beating cardiomyocytes as alternative for animal testing. Toxicology in Vitro, 29(2), 281-288.

https://doi.org/10.1016/j.tiv.2014.11.010 


\title{
In vitro detection of cardiotoxins or neurotoxins affecting ion channels or pumps using beating cardiomyocytes as alternative for animal testing
}

\author{
J. Nicolas \\ P.J.M. Hendriksen \\ L.H.J de Haan \\ R. Koning \\ I.M.C.M. Rietjens \\ T.F.H. Bovee
}




\begin{abstract}
The present study investigated if and to what extent murine stem cell-derived beating cardiomyocytes within embryoid bodies can be used as a broad screening in vitro assay for neurotoxicity testing, replacing for example in vivo tests for marine neurotoxins. Effect of nine model compounds, acting on either the $\mathrm{Na}^{+}, \mathrm{K}^{+}$, or $\mathrm{Ca}^{2+}$ channels or the $\mathrm{Na}^{+} / \mathrm{K}^{+}$-ATPase pump, on the beating was assessed. Diphenhydramine, veratridine, isradipine, verapamil and ouabain induced specific beating arrests that were reversible and none of the concentrations tested induced cytotoxicity. Three $\mathrm{K}^{+}$channel blockers, amiodarone, clofilium and sematilide, and the $\mathrm{Na}^{+} / \mathrm{K}^{+}$-ATPase pump inhibitor digoxin had no specific effect on the beating. In addition, two marine neurotoxins i.e. saxitoxin and tetrodotoxin elicited specific beating arrests in cardiomyocytes. Comparison of the results obtained with cardiomyocytes to those obtained with the neuroblastoma neuro-2a assay revealed that the cardiomyocytes were generally somewhat more sensitive for the model compounds affecting $\mathrm{Na}^{+}$and $\mathrm{Ca}^{2+}$ channels, but less sensitive for the compounds affecting $\mathrm{K}^{+}$channels. The stem cell-derived cardiomyocytes were not as sensitive as the neuroblastoma neuro-2a assay for saxitoxin and tetrodotoxin. It is concluded that the murine stem cell-derived beating cardiomyocytes provide a sensitive model for detection of specific neurotoxins and that the neuroblastoma neuro-2a assay may be a more promising cellbased assay for the screening of marine biotoxins.
\end{abstract}




\section{Introduction}

During the last two decades, the in vitro embryonic stem cell test (EST), in which murine D3 cells are induced to differentiate into beating cardiomyocytes formed in attached embryoid bodies (EBs), has been successfully implemented and validated by the European Centre for the Validation of Alternative Methods (ECVAM) for the assessment of embryo toxicity [1]. Where embryo toxicity is assessed by the effect of a compound on the differentiation process, the present study uses the beating cardiomyocytes within EBs as a model to study effects of neurotoxic compounds. The mechanism behind the contractions of the cardiomyocytes involves $\mathrm{Na}^{+}, \mathrm{Ca}^{2+}, \mathrm{K}^{+}$channels and the $\mathrm{Na}^{+} / \mathrm{K}^{+}$-ATPase pump. These channels and pump are also involved in the generation of the action potential in neuronal cells and are important for a wide range of physiological processes, including intracellular messaging, regulation of cell volume, regulation of gene expression, synaptic transmission, and cardiac excitation-contraction coupling [2]. The blockade or opening of these ion channels results in a disturbance of the ion homeostasis that in turn affects the physiology and action potentials of the cells. Figure 4.1 describes which channels are involved in the generation of action potentials both in cardiac and neuronal cells [3]. Although action potentials in the heart (both in pacemaker cells and in cardiomyocytes) and neurons are driven by similar ionic fluxes $\left(\mathrm{Na}^{+}, \mathrm{K}^{+}\right.$and $\left.\mathrm{Ca}^{2+}\right)$, different ion channel subtypes exist, resulting in different specificity and sensitivity towards different neurotoxins [4]. However, despite the differences, murine embryonic stem cell-derived beating cardiomyocytes might be a promising model for the detection of neurotoxic compounds, including marine neurotoxins, because $\mathrm{Na}^{+}, \mathrm{Ca}^{2+}$ and $\mathrm{K}^{+}$channels and the $\mathrm{Na}^{+} / \mathrm{K}^{+}$-ATPase pump are the target of a wide range of neurotoxic compounds [5-7]. Marine biotoxins are naturally occurring chemicals produced by microscopic algae. They accumulate in fish and shellfish and therefore represent a threat for consumers. The current standard for the detection of marine biotoxins in seafood is the in vivo mouse bioassay (MBA), in which mice are injected with sample extracts and death is the final readout. More recently, a chemical analytical LC/MS-MS method was EU approved/accepted but many countries still use the MBA, as the chemical analysis method is not able to detect all known toxins and misses unknown toxins. Extensive information on marine biotoxins can be found in recent reviews [8, 9]. In line with the 3R concept of Russell and Burch, alternative in vitro assays to replace in vivo testing are urgently needed as in vivo tests are considered as 
highly unethical [10]. In the case of marine biotoxins, the mouse test will be forbidden from 2015 onwards, except for the control of production areas where seafood produced is intended for future consumption [11].
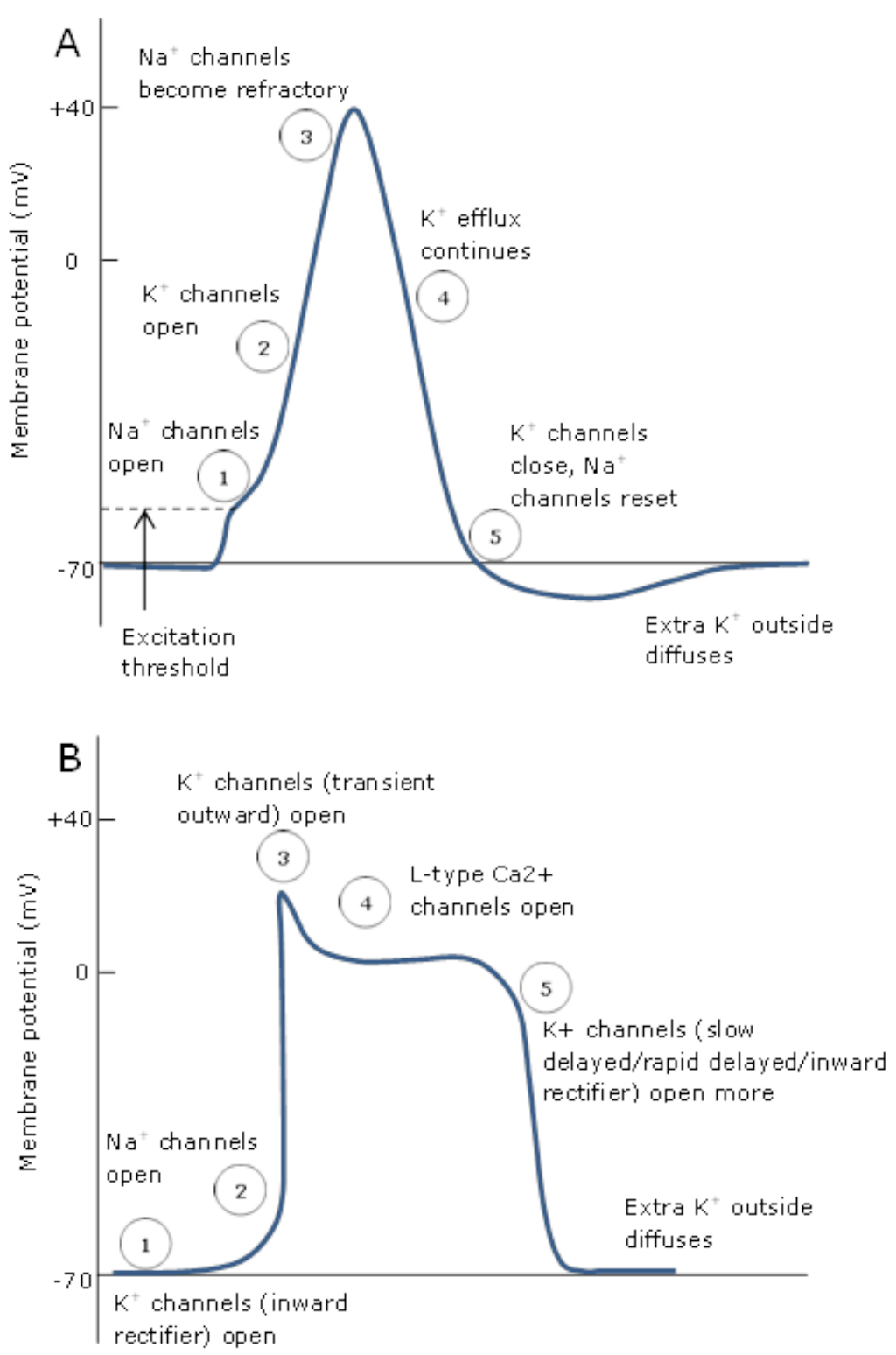

Figure 4.1: Overview of ion channels and fluxes involved in the generation of action potentials in A) neuronal cells and B) cardiomyocytes (based on [2, 3]). A) A stimulus increases the membrane potential above the excitation threshold until $+40 \mathrm{mV}$ thanks to $\mathrm{Na}+$ influx. At +40 $\mathrm{mV}$ an efflux of $\mathrm{K}^{+}$ions brings the membrane potential back to $-70 \mathrm{mV}$. B) $\mathrm{K}+$ and $\mathrm{Na}+$ influxes raise the membrane potential from -70 to $+20 \mathrm{mV}$. Na+ channels close and L-type Ca2+ channels open, causing a plateau. $\mathrm{K}+$ channels open decreasing the membrane potential back to its initial value of $-70 \mathrm{mV}$. 
Maltsev et al. (1994) showed that all basic cardiac-specific channels are present in murine embryonic stem cell-derived cardiomyocytes [12]. Since neurons and cardiomyocytes share many ion channels [13] and a wide range of neurotoxic compounds are known to act on ion channels, we hypothesized that beating cardiomyocytes might be suitable as an in vitro tool to detect the potential neurotoxic effects of compounds, including marine neurotoxins. Based on these considerations the aim of the present study was to assess whether and to what extent embryonic stem cell-derived cardiomyocytes could be used as an in vitro assay for the screening of neurotoxic compounds. To this end cardiomyocytes formed in EBs were exposed to different neurotoxins, using the contractility (i.e. the inotropy) of the cardiomyocytes within the EBs as a read-out. Nine model neurotoxins were selected that are known to affect either one of the three types of channels or the $\mathrm{Na}^{+} / \mathrm{K}^{+}$-ATPase pump (Tab. 4.1). In addition to these nine model neurotoxins, two commercially available pure marine neurotoxins were tested: saxitoxin (STX) and tetrodotoxin (TTX) ( $\mathrm{Na}^{+}$channel blockers) in order to establish whether this assay may be of value as a replacement of the in vivo assays currently used for the screening of marine biotoxins in seafood. Moreover, the nine model compounds and STX and TTX were also tested in the neuroblastoma neuro-2a assay in order to compare the sensitivity of the embryonic stem cellderived cardiomyocytes to the sensitivity of the neuro-2a cells, as the latter is currently regarded as a promising cell-based assay for the screening of marine biotoxins in seafood [8, 14]. 
Table 4.1. Inhibition of beatings in contractile embryonic stem cell-derived cardiomyocytes and effect on the viability in the neuro-2a assay.

\begin{tabular}{|c|c|c|c|c|c|}
\hline Compound & Mode of action & References $^{\mathbf{a}}$ & $\begin{array}{c}\text { \% cell viability at the } \\
\text { noted drug } \\
\text { concentration } \\
\text { (differentiated }\end{array}$ & $\begin{array}{c}\mathrm{EC}_{50} \\
\text { differentiated } \\
\text { cardiomyocytes }^{\mathbf{c}}\end{array}$ & $\begin{array}{c}\mathrm{EC}_{50} \\
\text { neuro-2ac }\end{array}$ \\
\hline Diphenhydramine & $\begin{array}{l}\mathrm{Na}^{+} \text {channel } \\
\text { blocker }\end{array}$ & {$[15,16]$} & $150 \mu \mathrm{M}: 104 \pm 14$ & $45 \mu \mathrm{M}$ & $>100 \mu \mathrm{M}$ \\
\hline Veratridine & $\begin{array}{l}\mathrm{Na}^{+} \\
\text {opener }\end{array}$ & $\begin{array}{l}{[17,18]\left(E_{50}:\right.} \\
85 \mu \mathrm{M})\end{array}$ & $100 \mu \mathrm{M}: 114 \pm 6$ & $35 \mu \mathrm{M}$ & $90 \mu \mathrm{M}$ \\
\hline Isradipine & $\begin{array}{l}\mathrm{Ca}^{2+} \quad \text { channel } \\
\text { blocker }\end{array}$ & [19] & $100 \mu \mathrm{M}: 113 \pm 23$ & $15 \mu \mathrm{M}$ & $>100 \mu \mathrm{M}$ \\
\hline Verapamil & $\begin{array}{l}\mathrm{Ca}^{2+} \quad \text { channel } \\
\text { blocker }\end{array}$ & $\begin{array}{l}{[20,21]\left(E_{50}:\right.} \\
19 \mu \mathrm{M})\end{array}$ & $1 \mu \mathrm{M}: 106 \pm 10$ & $100 \mathrm{nM}$ & $190 \mathrm{nM}$ \\
\hline Sematilide & $\begin{array}{l}\mathrm{K}^{+} \quad \text { channel } \\
\text { blocker }\end{array}$ & {$[22]$} & $500 \mu \mathrm{M}: 95 \pm 10$ & $>400 \mu \mathrm{M}$ & $>300 \mu \mathrm{M}$ \\
\hline Clofilium & $\begin{array}{l}\mathrm{K}^{+} \quad \text { channel } \\
\text { blocker }\end{array}$ & {$[23]$} & $500 \mu \mathrm{M}: 51 \pm 0.25$ & $\begin{array}{l}207 \mu \mathrm{M} \text { due to } \\
\text { cytotoxicity }\end{array}$ & $150 \mu \mathrm{M}$ \\
\hline Amiodarone & $\begin{array}{l}\mathrm{K}^{+} \quad \text { channel } \\
\text { blocker }\end{array}$ & [24] & $60 \mu \mathrm{M}: 54 \pm 1$ & $>60 \mu \mathrm{M}$ & $80 \mu \mathrm{M}$ \\
\hline Ouabain & $\begin{array}{l}\mathrm{Na}^{+} / \mathrm{K}^{+} \text {ATPase } \\
\text { blocker }\end{array}$ & $\begin{array}{l}{[25] \quad\left(\mathrm{EC}_{50}:\right.} \\
370 \mu \mathrm{M})\end{array}$ & $600 \mu \mathrm{M}: 86 \pm 4$ & $257 \mu \mathrm{M}$ & $220 \mu \mathrm{M}$ \\
\hline Digoxin & $\begin{array}{l}\mathrm{Na}^{+} / \mathrm{K}^{+} \text {ATPase } \\
\text { inhibitor }\end{array}$ & {$[26]$} & $160 \mu \mathrm{M}: 64 \pm 4$ & $>150 \mu \mathrm{M}$ & $>100 \mu \mathrm{M}$ \\
\hline Saxitoxin & $\begin{array}{l}\mathrm{Na}^{+} \quad \text { channel } \\
\text { blocker }\end{array}$ & [27] & $\begin{array}{l}\text { No cytotoxicity up to } 1 \\
\mu \mathrm{M}\end{array}$ & $4 \mu \mathrm{M}$ & $\begin{array}{l}\text { With o/v: } \\
11 \mathrm{nM}\end{array}$ \\
\hline Tetrodotoxin & $\begin{array}{l}\mathrm{Na}^{+} \quad \text { channel } \\
\text { blocker }\end{array}$ & {$[28]$} & $\begin{array}{l}\text { No cytotoxicity up to } 10 \\
\mu \mathrm{M}\end{array}$ & $\begin{array}{l}10 \mu \mathrm{M} \quad \text { (with } \\
\text { veratridine) }\end{array}$ & $\begin{array}{l}\text { With o/v: } \\
10 \mathrm{nM}\end{array}$ \\
\hline
\end{tabular}

${ }^{\mathrm{a}}$ The references stand for the modes of action of the selected model compounds and the $\mathrm{EC}_{50}$ values are mentioned when available. ${ }^{\mathrm{b}}$ The percentage of cell viability was determined at concentrations above those which elicited effects on beatings of cardiomyocytes following a 24 hour exposure to the compounds. ${ }^{\mathrm{c}}$ The $\mathrm{EC}_{50}$ values were calculated using a non-linear regression model. o/v: ouabain/veratridine. 


\section{Materials and Methods}

\section{Chemicals}

Amiodarone, clofilium, digoxin, diphenhydramine, isradipine, ouabain, sematilide, verapamil, and veratridine were purchased from Sigma-Aldrich (St. Louis, USA) and dimethylsulfoxide (DMSO) was obtained from Acros Organic (New Jersey, USA). STX was purchased from the National Research Council (Montreal, Canada) and TTX from Latoxan (Valence, France). Compound stock solutions were prepared in DMSO.

\section{Cell lines and cell culture}

The murine-derived embryonic stem cell line D3 was kindly donated by Johnson \& Johnson (Beerse, Belgium). The cells were cultured in flasks of $25 \mathrm{~cm}^{2}$ (Corning Inc., Cambridge, USA) in Dulbecco's modified Eagle's medium (DMEM) (Invitrogen, Breda, The Netherlands) supplemented with 20\% (v/v) heat inactivated fetal calf serum (FCS) (BioWhittaker, Maryland, USA), $1 \%(\mathrm{v} / \mathrm{v})$ non-essential amino acids (Invitrogen), $50 \mathrm{U} / \mathrm{mL}$ penicillin/50 $\mu \mathrm{g} / \mathrm{mL}$ streptomycin (P/S) (Invitrogen), $2 \mathrm{mM}$ L-glutamine (Invitrogen) and $0.1 \mathrm{mM} ß$-mercaptoethanol (Sigma-Aldrich). To prevent cell differentiation, $1000 \mathrm{U} / \mathrm{mL}$ murine leukemia inhibitory factor (Sigma-Aldrich) was added to the medium when cells were seeded. The cells were cultured in a humidified atmosphere $\left(37^{\circ} \mathrm{C}, 5 \% \mathrm{CO}_{2}\right)$ and subcultured three times a week. The cells were detached when reaching $80 \%$ confluence using non-enzymatic dissociation buffer (SigmaAldrich).

Neuro-2a cells (LGC standards, Middlesex, UK) were cultured in flasks of $75 \mathrm{~cm}^{2}$ using $10 \%$ FBS/Roswell Park Memorial Institute medium (RPMI-1640) supplemented with 1\% 5000 U/mL penicillin/5 mg/mL streptomycin (P/S) (Invitrogen), $2 \mathrm{mM}$ L-glutamine (Invitrogen) and $1 \mathrm{mM}$ sodium pyruvate (Sigma-Aldrich). Cells were cultured at $37^{\circ} \mathrm{C}, 5 \% \mathrm{CO}_{2}$ and subcultured 3 times per week. The cells were detached when reaching $80 \%$ confluence using trypsin (SigmaAldrich). 


\section{Embryonic stem cell test}

The embryonic stem cell test was performed as described previously [29] with some minor modifications. For the differentiation process, hanging drops of $20 \mu \mathrm{l}$ cell suspension (3.75.10 4 cells/mL) were prepared at day 0 on the cover of 96-well plates. Phosphate buffered saline (250 $\mu \mathrm{L}$ ) was put in each well in order to maintain humidity and prevent evaporation of the hanging drops. Cells in hanging drops were allowed to differentiate for 3 days in the humidified atmosphere $\left(37^{\circ} \mathrm{C}, 5 \% \mathrm{CO}_{2}\right)$, and at day 3 , the cell aggregates formed (called EBs) were transferred to bacterial petri dishes (Greiner Bio-one, Alphen a/d Rijn, The Netherlands) and incubated for 3 days. At day 5, the EBs were plated in 96-well plates (Corning, $1 \mathrm{~EB} / \mathrm{well}$ ) and incubated for 5 days. The cardiomyocytes started beating on day 10 .

At day 13, when most EBs have beating areas, beating EBs were incubated with the neurotoxic compounds for $1 \mathrm{~h}\left(37^{\circ} \mathrm{C}, 5 \% \mathrm{CO}_{2}\right)$. Ten beating EBs per concentration were exposed to the different compounds selected (final DMSO solvent concentration of $0.25 \%$ ) and the number of remaining beating EBs after one hour incubation was scored by visual inspection (beating arrest). Subsequently, cells were washed and the medium was replaced by medium without the test compound, and the EBs were incubated for an additional hour after which the contractility of the EBs was assessed again to evaluate recovery. At least three independent experiments with six replicates were performed per concentration for each compound. In the case of STX, five instead of ten EBs were exposed and the number of beating EBs were scored after 20 hours of incubation instead of one hour. The control for STX was a solution of $\mathrm{HCl}(0.003 \mathrm{M})$ as commercial STX is dissolved in HCl. Because TTX alone did not affect the beatings and TTX, being a sodium channel blocker, has an opposite mode of action as veratridine which acts as a sodium channel activator, two experimental designs were tested to evaluate whether TTX could prevent beating arrest following veratridine exposure: ten EBs were exposed to $10 \mu \mathrm{M}$ of TTX for 5 minutes and then exposed to $100 \mu \mathrm{M}$ of veratridine for one hour and in another experiment, ten EBs were exposed to $100 \mu \mathrm{M}$ of veratridine for $1 \mathrm{~h}$ followed by an exposure to $10 \mu \mathrm{M}$ of TTX for an additional hour. 


\section{Cell viability}

Cell viability was assessed with the WST-1 assay by measuring mitochondrial activity (Roche, Woerden, The Netherlands) for embryonic stem cell-derived cardiomyocytes. The viability of the cardiomyocytes within EBs was assessed 24 hours after exposure to the different compounds and vehicle. To this end, $20 \mu \mathrm{L}$ of WST-1 solution was added to each well containing $200 \mu \mathrm{L}$ of medium. After incubation for $3 \mathrm{~h}\left(37^{\circ} \mathrm{C}, 5 \% \mathrm{CO}_{2}\right)$, the absorbance was determined spectrophotometrically at $450 \mathrm{~nm}$. The mitochondrial activity was expressed as percentage of the average of the vehicle control (DMSO solvent).

\section{Neuro-2a assay}

Cells were grown for 24 hours and subsequently exposed for 24 hours to the marine neurotoxins with and without a combination of ouabain/veratridine. Concentrations of ouabain/veratridine inducing about $80 \%$ cytotoxicity were selected, in order to evaluate the toxin's ability to oppose or prevent the cytotoxicity induced by this $\mathrm{Na}^{+}$channel opener (veratridine) and $\mathrm{Na}^{+} / \mathrm{K}^{+}$-ATPase pump blocker (ouabain). Cell viability of neuro-2a cells was assessed with the 3-(4,5dimethylthiazol-2-yl)-2,5-diphenyltetrazolium bromide (MTT) assay (Sigma-Aldrich) measuring the mitochondrial activity. Absorbance was read on a spectrophotometer at $570 \mathrm{~nm}$ and the mitochondrial activity was expressed as percentage of the average of the vehicle control (DMSO).

\section{Data analysis}

In this study, the $\mathrm{EC}_{50}$ of a compound is the concentration at which $50 \%$ of the maximum inhibiting effect on the contractility of the cardiomyocytes was induced. The $\mathrm{EC}_{50}$ values and their 95\% confidence intervals (CI) were calculated using GraphPad Prism (San Diego, CA). When no inhibition of the contractility occurred, no EC 50 value could be calculated (Tab. 4.1).

For the establishment of dose-response curves and the determination of $\mathrm{EC}_{50}$ values for the neuro-2a assay, cell viability for each concentration of each model compound or marine neurotoxin after a 24 hour exposure was measured at least in duplicate. In this assay, the $\mathrm{EC}_{50}$ is the concentration at which $50 \%$ of the cytotoxicity occurs following exposure to the model 
compounds and the concentration at which 50\% of the cytotoxic effect caused by ouabain/veratridine is opposed following exposure to the marine neurotoxins.

\section{Results}

With the embryonic stem cell test (EST), the proportion of beating EBs is the read-out and cell viability was assessed by the WST-1 assay as the MTT yielded unreliable results (due to loss of cells during the removal of the medium), while in the neuro-2a assay, the cell viability is the read-out and was assessed by the MTT assay as the neuro-2a cells were well attached to the bottom of each well. Moreover, in the neuro-2a MTT assay, STX and TTX and the nine neurotoxic model compounds were also tested in combination with a dose of ouabain/veratridine that caused a $80 \%$ decrease in cell viability in order to determine whether the toxin was able to oppose the effect, i.e. to counteract the cytotoxicity induced by ouabain/veratridine [14]. However, none of the nine neurotoxic model compounds was able to oppose the cytotoxicity induced by ouabain/veratridine, and these results are not further discussed or shown.

\section{$\mathrm{Na}^{+}$channels}

The $\mathrm{Na}^{+}$channel blocker diphenhydramine inhibited beating of cardiomyocytes at and above a concentration of $25 \mu \mathrm{M}\left(\mathrm{EC}_{50}=45 \mu \mathrm{M}\right.$, Tab. 4.1). A concentration of $100 \mu \mathrm{M}$ elicited beating arrests of all EBs (Fig. 4.2A). This beating arrest was completely reversible, as upon refreshing the medium, all EBs started to beat again. Veratridine induced a concentration-dependent decrease of the proportion of beating EBs at concentrations at and higher than $25 \mu \mathrm{M}\left(\mathrm{EC}_{50}=35\right.$ $\mu \mathrm{M}$, Tab. 4.1). When the cells were exposed to 60 and $100 \mu \mathrm{M}$, all EBs stopped beating. After a recovery period of $1 \mathrm{~h}$, every EB that stopped beating after exposure to $60 \mu \mathrm{M}$ of veratridine started beating again, while for $100 \mu \mathrm{M} 80 \%$ of the EBs recovered (Fig. 4.2B). The cell viability was not affected by both compounds according to the results obtained with the WST-1 assay (Tab. 4.1). 

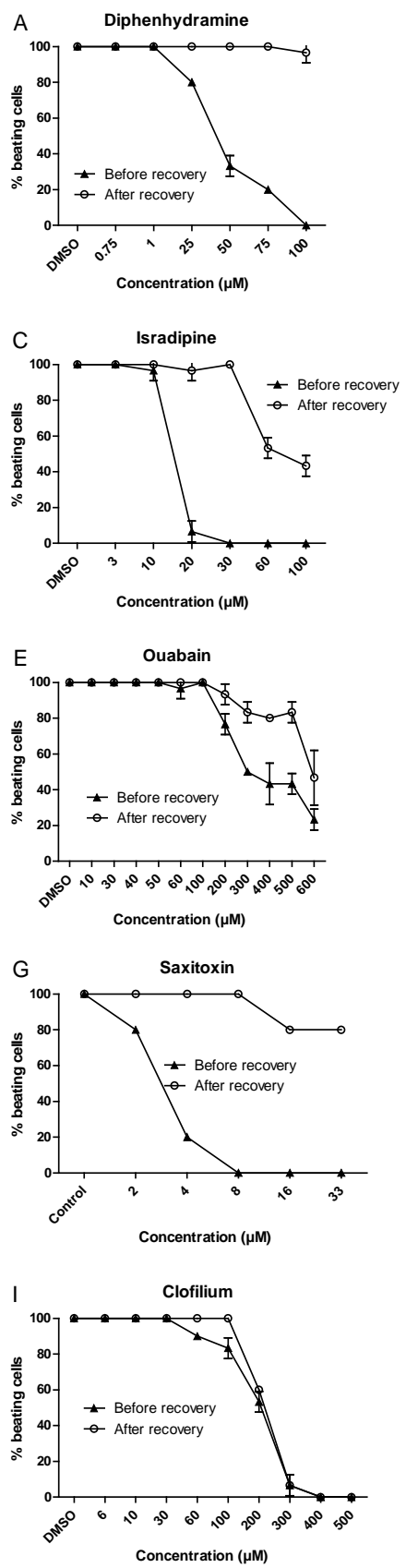
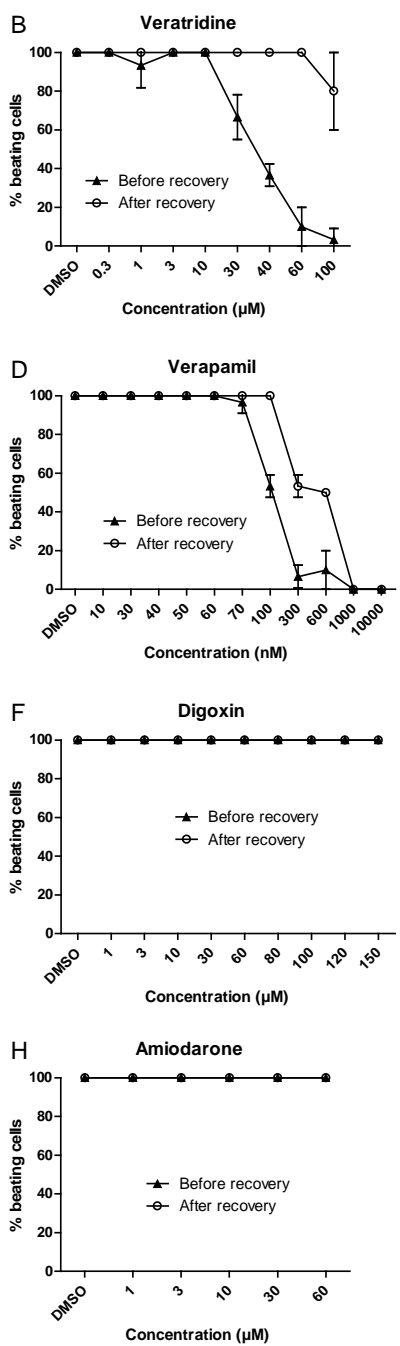

Concentration $(\mu \mathrm{M})$

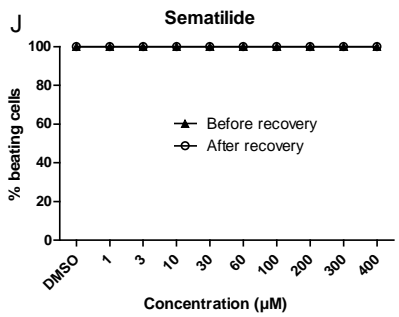

Figure 4.2: Effect of A) the $\mathrm{Na}^{+}$channel blocker diphenhydramine, B) the $\mathrm{Na}^{+}$channel opener veratridine, C-D) the $\mathrm{Ca}^{2+}$ channel blockers isradipine and verapamil, E-F) the $\mathrm{Na}^{+} / \mathrm{K}^{+}$-ATPase blockers ouabain and digoxin, $\mathrm{G}$ ) the $\mathrm{Na}^{+}$channel blocker STX, H-I-J) the $\mathrm{K}^{+}$channel blockers amiodarone, clofilium and sematilide on the beating of embryonic stem cell-derived cardiomyocytes. Upon exposure the EBs were incubated with fresh medium for an additional hour to assess the recovery. The data are presented as the mean of 3 experiments \pm SD. $0.3 \%$ DMSO or $\mathrm{HCl}$, used as solvent controls, had no effect on cell viability. At least three independent experiments with ten replicates were performed per concentration for each compound. 
Figure 4.3A and 4.3B show that in the neuro-2a assay, diphenhydramine slightly decreased cell viability while veratridine induced a concentration-dependent decrease in cell viability $\left(\mathrm{EC}_{50}=\right.$ $90 \mu \mathrm{M}$, Tab. 4.1).
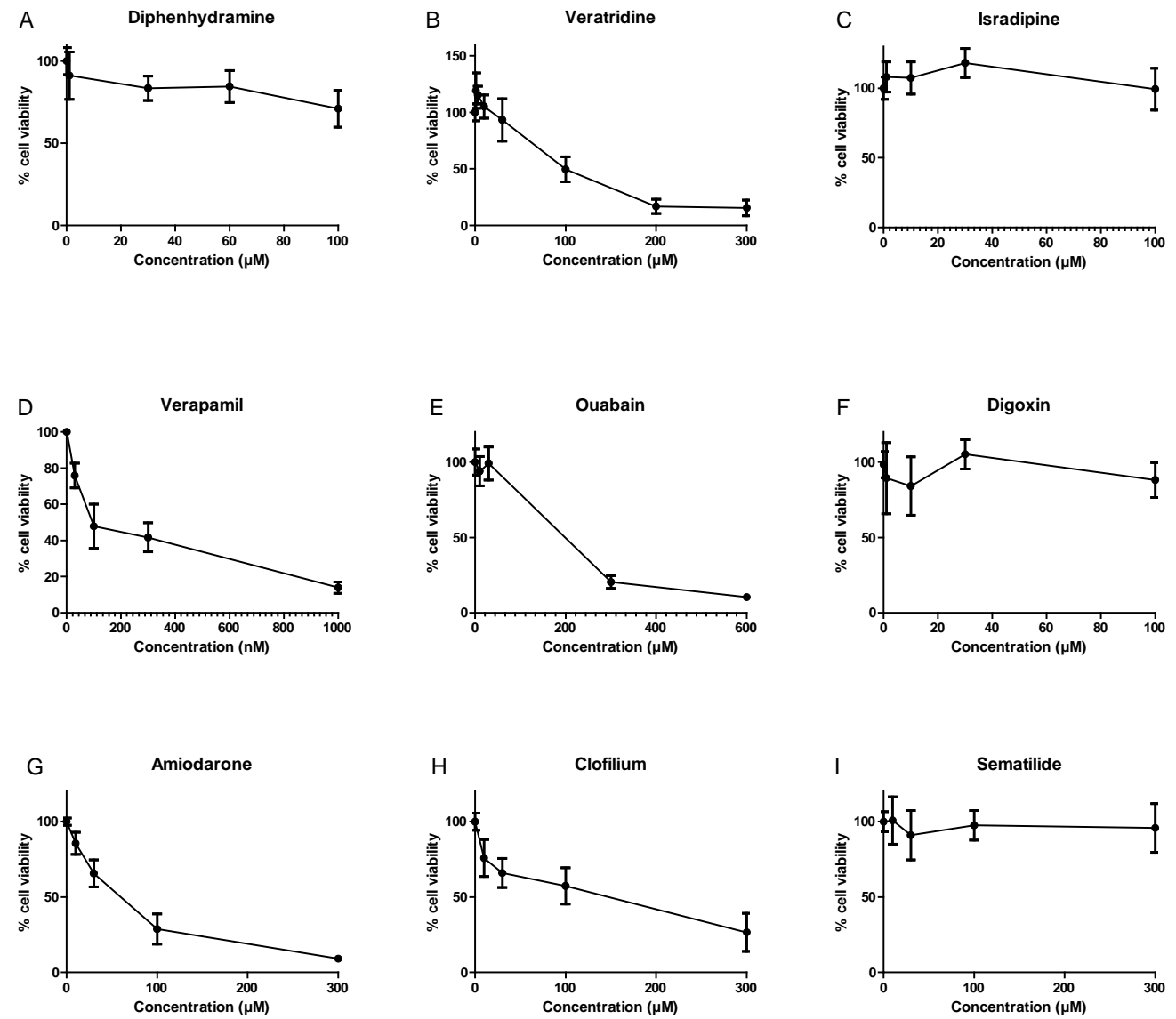

Figure 4.3: Effect of A) the $\mathrm{Na}^{+}$channel blocker diphenhydramine, B) the $\mathrm{Na}^{+}$channel opener veratridine, C-D) the $\mathrm{Ca}^{2+}$ channel blockers isradipine and verapamil, E-F) the $\mathrm{Na}^{+} / \mathrm{K}^{+}$-ATPase blockers ouabain and digoxin, G-H-I) the $\mathrm{K}^{+}$channel blockers amiodarone, clofilium and sematilide on the cell viability of neuro-2a cells. The cells were exposed for 24 hours and cell viability was assessed using the MTT assay. At least three independent experiments with six replicates were performed per concentration for each compound.

The embryonic stem cell-derived cardiomyocytes are thus more sensitive to diphenhydramine and veratridine than the neuro-2a cells. 


\section{$\mathrm{Ca}^{2+}$ channels}

Figure 4.2C shows that the $\mathrm{Ca}^{2+}$ channel blocker isradipine at concentrations of $20 \mu \mathrm{M}$ and higher caused beating arrests in every exposed $\mathrm{EB}\left(\mathrm{EC}_{50}=15 \mu \mathrm{M}\right.$, Tab. 4.1). After exposure to up to $30 \mu \mathrm{M}$ isradipine, all EBs recovered after refreshment of the medium. After exposure to 60 or $100 \mu \mathrm{M}$ israpidine, $50 \%$ of the EBs recovered after medium refreshment. The other $\mathrm{Ca}^{2+}$ channel blocker, verapamil, induced beating arrests at concentrations from $100 \mathrm{nM}$ onwards. Where $100 \mathrm{nM}$ of verapamil induced beating arrest in half of the EBs, all EBs stopped beating at 300 and $1000 \mathrm{nM}\left(\mathrm{EC}_{50}=100 \mathrm{nM}\right.$, Tab. 4.1). All EBs recovered at $100 \mathrm{nM}$, while 50\% recovered at $300 \mathrm{nM}$ and $600 \mathrm{nM}$. At concentrations of $1000 \mathrm{nM}$ and higher, the cells did not recover anymore (Fig. 4.2D). The WST-1 tests showed that cell viability was not affected by the tested concentrations of isradipine or verapamil (Tab. 4.1).

Figure 4.3C and 4.3D show that in the neuro-2a assay, isradipine up to $100 \mu \mathrm{M}$ had no effect on the cell viability, while verapamil at concentrations of $30 \mathrm{nM}$ and higher induced a decrease in cell viability.

The determined $\mathrm{EC}_{50}$ values show that the embryonic stem cell-derived cardiomyocytes are more sensitive for isradipine than neuro-2a cells, and also slightly more sensitive for verapamil (Tab. 4.1).

\section{$K^{+}$channels}

None of the $\mathrm{K}^{+}$channel blockers induced beating arrests of the EBs at non-cytotoxic concentrations: amiodarone up to $60 \mu \mathrm{M}$, clofilium up to $100 \mu \mathrm{M}$ and sematilide up to $400 \mu \mathrm{M}$ had no effect on the beating (Fig. 4.2H-I-J). The cell viability was affected by amiodarone but not by sematilide according to the results obtained with the WST-1 assay (Tab. 4.1). However, higher concentrations of clofilium from $100 \mu \mathrm{M}$ onwards induced cytotoxicity (WST-1 assay, Tab. 4.1), and the resulting beating arrests were thus not due to the $\mathrm{K}^{+}$channel blockade. In accordance with this observation, none of the EBs exposed to high levels of clofilium recovered (Fig. 4.2I).

In the neuro-2a assay, amiodarone and clofilium at and above a concentration of $10 \mu \mathrm{M}$ induced a decrease in cell viability, while sematilide had no effect up to $300 \mu \mathrm{M}$ (Fig. 4.3G-H-I). 
The neuro-2a cells are thus more sensitive to amiodarone and clofilium than the embryonic stem cell-derived cardiomyocytes, while both cell assays were insensitive for sematilide (Tab. 4.1).

\section{$\mathrm{Na}^{+} / \mathrm{K}^{+}$-ATPase pump}

Figure 4.2E shows the effects of the $\mathrm{Na}^{+} / \mathrm{K}^{+}$-ATPase pump blocker ouabain on the beating of the cardiomyocytes. Concentrations up to $100 \mu \mathrm{M}$ of ouabain did not induce a beating arrest in the EBs. At concentrations of $200 \mu \mathrm{M}$ and higher, ouabain induced a concentration-dependent decrease in the percentage of beating cells $\left(\mathrm{EC}_{50}=257 \mu \mathrm{M}\right.$, Tab. 4.1). While most EBs recovered from the $300 \mu \mathrm{M}$ exposure, almost none of the EBs that stopped beating at $600 \mu \mathrm{M}$ recovered after the medium refreshment. It should be mentioned that the beating rates of some EBs that did not stop beating after exposure to ouabain (up to $100 \mu \mathrm{M}$ ) were largely increased (increased beating frequency not quantified) and this increased beating frequency may also reflect neurotoxicity. The $\mathrm{Na}^{+} / \mathrm{K}^{+}$-ATPase pump inhibitor digoxin did not affect the beating of the cells up to $150 \mu \mathrm{M}$ (Fig. 4.2F). According to the outcomes of the WST-1 assay, the viability of the cardiomyocytes was not affected by ouabain but slightly affected by digoxin at $160 \mu \mathrm{M}$ (Tab. 4.1).

Ouabain at concentrations of $300 \mu \mathrm{M}$ and higher induced a decrease in cell viability of neuro2a cells and digoxin up to $100 \mu \mathrm{M}$ did not affect cell viability of neuro-2a cells (Fig. 4.3E and 4.3F). The two assays thus display a similar sensitivity towards these $\mathrm{Na}^{+} / \mathrm{K}^{+}$-ATPase pump inhibitors.

\section{Marine biotoxins: Proof of principle}

Figure 4.2G shows the effects of the commercially available $\mathrm{Na}^{+}$channel blocker STX on the beating of cardiomyocytes after 20 hours of exposure. As no beating arrest was observed after a 1 hour exposure to STX, the EBs were checked every hour for 6 hours and after 20 hours. STX only induced a concentration dependent decrease in the beating of the cardiomyocytes after a period of 20 hours $\left(\mathrm{EC}_{50}=3.9 \mu \mathrm{M}\right.$, Tab. 4.1). Every EB exposed to concentrations of STX up to $8 \mu \mathrm{M}$ recovered, while $80 \%$ of them recovered at 16 and $33 \mu \mathrm{M}$. TTX up to $60 \mu \mathrm{M}$ did not alter 
the beating of cardiomyocytes after an exposure of 24 hours. Neither STX nor TTX had an effect on the viability of embryonic stem cell-derived cardiomyocytes (WST-1 assay, Tab. 4.1).
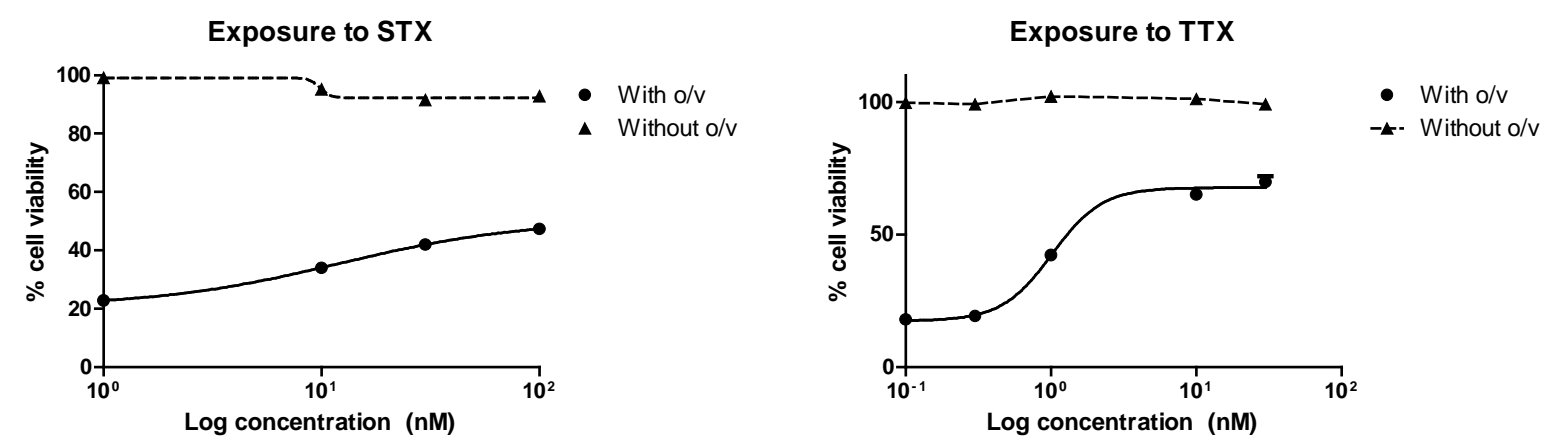

Figure 4.4: Effect of the $\mathrm{Na}^{+}$channel blockers saxitoxin and tetrodotoxin on the viability of neuro-2a cells, with (plain line) or without (dashed line) ouabain/veratridine. The cells were exposed to ouabain/veratridine and STX or TTX at the same time. The cell viability of the cells exposed to ouabain/veratridine alone was about $20 \%$. No cytotoxicity was induced by STX and TTX without ouabain/veratridine (dashed line). At least three independent experiments with six replicates were performed per concentration for each compound.

Because TTX and veratridine have opposite modes of action, TTX being a $\mathrm{Na}^{+}$channel blocker and veratridine a $\mathrm{Na}^{+}$channel activator, it was hypothesized that TTX could prevent the beating arrest induced by veratridine. Indeed, exposing the cardiomyocytes to $100 \mu \mathrm{M}$ of veratridine for 1 hour, resulting in a beating arrest of all EBs, and then adding TTX to a final concentration of $10 \mu \mathrm{M}$ in each well during an additional hour, resulted in a $100 \%$ recovery of the beating. In addition, when the cells were pre-treated with $10 \mu \mathrm{M}$ of TTX during 5 minutes and then exposed to $100 \mu \mathrm{M}$ of veratridine for one hour, none of the EBs stopped beating.

Without ouabain/veratridine STX and TTX did not induce cytotoxicity in the neuro-2a cells. However, when co-incubated with ouabain/veratridine, STX and TTX increased cell viability in the neuro-2a cells at and above $10 \mathrm{nM}$ and $3 \mathrm{nM}$ respectively (Fig. 4.4). These data show that the neuro-2a cells are more sensitive for these marine biotoxins than cardiomyocytes (Tab. 4.1). 


\section{Discussion}

Diphenhydramine has been reported to block $\mathrm{Na}^{+}$channels in neurons at a concentration of 100 $\mu \mathrm{M}$ [16]. Without a $\mathrm{Na}^{+}$influx, cardiac cells cannot generate action potentials and cardiomyocytes are therefore not able to beat. However, diphenhydramine did not decrease cell viability of neuro-2a cells, indicating that either neuro-2a cells do not express the $\mathrm{Na}^{+}$channel subtypes targeted by diphenhydramine or blockade of these channel subtypes does not affect cell viability.

The $\mathrm{Na}^{+}$channel opener veratridine causes an abnormal entry of $\mathrm{Na}^{+}$ions followed by a secondary increase of the $\mathrm{Ca}^{2+}$ concentration, leading to beating arrests because the $\mathrm{Na}^{+}$channel is unable to close [30]. The sensitivity of the murine embryonic stem cell-derived beating cardiomyocytes to veratridine in the present study, i.e. $\mathrm{EC}_{50}=35 \mu \mathrm{M}$, is comparable to what has been found by Yanagita et al. in 2003, reporting an increase of $\mathrm{Na}^{+}$influx by veratridine with an $\mathrm{EC}_{50}$ of $85 \mu \mathrm{M}$ in adrenal chromaffin cells [18]. The neuro-2a assays showed a similar sensitivity to veratridine, as cell viability was affected with an $\mathrm{EC}_{50}$ of $90 \mu \mathrm{M}$.

Verapamil blocks the L- and T-type $\mathrm{Ca}^{2+}$ channels, while isradipine blocks only the L-type $\mathrm{Ca}^{2+}$ channels [31, 32]. In 1994, Keith et al. obtained an $\mathrm{EC}_{50}$ of $19 \mu \mathrm{M}$ for the synaptosomal inhibition of the $\mathrm{Ca}^{2+}$ influx by verapamil in rat cortical neurons [21]. The embryonic stem cellderived beating cardiomyocytes represent a more sensitive assay for the detection of verapamil, as specific beating arrests were observed for verapamil with an $\mathrm{EC}_{50}$ of $100 \mathrm{nM}$, which is also lower than the one obtained with the neuro-2a assay $\left(\mathrm{EC}_{50}=190 \mathrm{nM}\right)$. This indicates that embryonic stem cell-derived cardiomyocytes cells are relatively sensitive to verapamil. The $\mathrm{EC}_{50}$ of isradipine $(15 \mu \mathrm{M})$ for inducing beating arrests was much higher than that for verapamil, most likely because this compound only blocks the L-type $\mathrm{Ca}^{2+}$ channels. Isradipine had no effect on the cell viability of neuro-2a cells. Together these data suggest that the neuro-2a cells only express the $\mathrm{T}$-type $\mathrm{Ca}^{2+}$ channels, making them sensitive to verapamil in the $\mu \mathrm{M}$ range, but do not express the L-type $\mathrm{Ca}^{2+}$ channels, making them insensitive to isradipine. Murine cardiomyocytes express both the L- and T-type $\mathrm{Ca}^{2+}$ channels and are therefore sensitive to both verapamil and isradipine.

The $\mathrm{K}^{+}$channel blockers amiodarone, clofilium and sematilide had no specific inhibiting effect on the beating cardiomyocytes. The $\mathrm{K}^{+}$channel isoforms on the surface of the murine 
embryonic stem cell-derived cardiomyocytes might be resistant to amiodarone, clofilium and sematilide or, in the case of clofilium, the concentrations that elicited beating arrests in the murine cardiomyocytes are too close to the concentrations that elicited general cytotoxicity. The neuro-2a assay was also insensitive to sematilide, but amiodarone and clofilium were found to affect cell viability.

The $\mathrm{Na}^{+} / \mathrm{K}^{+}$-ATPase pump blocker ouabain elicited specific beating arrests and decreased cell viability of neuro-2a with a similar sensitivity. The $\mathrm{EC}_{50}$ of $257 \mu \mathrm{M}$ obtained in the present study for ouabain is in line with the findings of Kagiava et al. [25] who showed that ouabain elicited neurotoxicity with an $\mathrm{EC}_{50}$ of $370 \pm 18 \mu \mathrm{M}$ in the mouse myelinated sciatic nerve fibres. Digoxin had no effect either on the beating (inotropy) of the cardiomyocytes in the EBs or on the cell viability of neuro-2a cells. This was expected as digoxin only decreases the function of the $\mathrm{Na}^{+} / \mathrm{K}^{+}$-ATPase pump and does not block it, However, digoxin appeared to affect beating frequency (chronotropy) in the cardiomyocytes which was not included as a read out in our test.

STX and TTX block $\mathrm{Na}^{+}$channels and therefore the cells cannot generate action potentials, reflecting a mode of action similar to that of diphenhydramine [33]. The incubation time with STX required to elicit beating arrests was 20 hours, while for all model neurotoxins tested one hour was sufficient. This difference may be due to the fact that STX may only partially block the $\mathrm{Na}^{+}$type channels expressed by the cardiomyocytes, resulting in residual amounts of $\mathrm{Na}^{+}$ions still entering the cells causing shortage of $\mathrm{Na}^{+}$and effects on the beating process only upon prolonged exposure. TTX did not have any effect on the beating up to $60 \mu \mathrm{M}$. However, none of the cardiomyocytes stopped beating with the combination of $10 \mu \mathrm{M}$ TTX with $100 \mu \mathrm{M}$ of the $\mathrm{Na}^{+}$channel opener veratridine, a concentration that stopped the beating of all EBs, indicating that co-exposure of the EBs to TTX with veratridine is suitable for detecting TTX. This finding is in line with the observation that TTX has been shown to block veratridine-induced effects [34]. STX or TTX had no effect on cell viability of neuro-2a cells without addition of ouabain/veratridine. However, neuro-2a cells swell and eventually lyse upon exposure to a combination of ouabain/veratridine that enhances sodium influx [35]. The $\mathrm{Na}^{+}$channel blocker STX has been shown to protect neuro-2a cells from the action of ouabain/veratridine [14]. Both STX and TTX prevented to a certain extent cytotoxicity induced by ouabain/veratridine in neuro2a cells. This indicates that the main voltage gated sodium channels present in neuro-2a cells are 
TTX-sensitive while in the cardiomyocytes these channels are less sensitive to TTX and most likely belong to the Nav1.5 channel subtypes [36].

Certain compounds affect channels that are not expressed on the surface of the murine cardiomyocytes such as the $\mathrm{N}$ - and R-type $\mathrm{Ca}^{2+}$ channels and will thus not be detected. Since $\mathrm{K}^{+}$ channel blockers tested negative their integrity was confirmed by showing their activity towards other endpoints. Amiodarone inhibited neuronal activity in rat cortical neurons [37]. Measuring effects on the beating rate or on the generation of action potentials as additional parameters, using for example multielectrode arrays [38], will most likely result in a more sensitive assay and might even result in an assay able to detect a wider range of neurotoxins. Ultimately, a model capable of detecting an extensive range of marine neurotoxins shall present a large variety of ion channels/pumps as well as neuronal receptors, the principal targets of such toxins.

In line with the findings from Maltsev et al. (1994) the data provided in the present study show that the murine cardiomyocytes have functional $\mathrm{Na}^{+}, \mathrm{Ca}^{2+}$ channels and $\mathrm{Na}^{+} / \mathrm{K}^{+}$-ATPase pump and that beating murine cardiomyocytes can be used as a model to detect specific neurotoxic effects of compounds on $\mathrm{Na}^{+}, \mathrm{Ca}^{2+}$ channels and the $\mathrm{Na}^{+} / \mathrm{K}^{+}$-ATPase pump, but not on $\mathrm{K}^{+}$channels [12]. The inhibition of beatings in the murine cardiomyocytes was shown to be reversible and to occur at concentrations below those affecting cytotoxicity, which implies that these effects are not due to overall cytotoxicity providing a more specific read out for neurotoxicity than the cytotoxicity endpoint as determined in the neuro-2a assay. This is an advantage of the cardiomyocytes assay over the neuro-2a cells, providing a way to avoid detection of false positives for neurotoxicity. Moreover, for the nine neurotoxic model compounds tested, the cardiomyocytes were generally somewhat more sensitive for those compounds that affect $\mathrm{Na}^{+}$and $\mathrm{Ca}^{2+}$ channels, but less sensitive towards the compounds that affect $\mathrm{K}^{+}$channels. The sensitivity of cardiac cells towards neurotoxins suggests that when neurotoxins affect ion channels or pumps they will also most likely exhibit cardiotoxicity.

However, while beating is a more specific endpoint than cytotoxicity, the process behind the differentiation of embryonic stem cells into cardiomyocytes is time consuming and labour intensive, hampering the implementation of such assay for screening purposes. Nevertheless, $\mathrm{EC}_{50}$ values obtained with neuro-2a cells were in the same order of magnitude as that of the cardiomyocyte data, which are based on a more specific endpoint than cytotoxicity, and therefore seem to validate the cytotoxicity endpoint used in the neuro-2a mouse neuroblastoma assay. In 
addition, a striking difference in sensitivity was observed for STX and TTX, for which the stem cell-derived cardiomyocytes were not as sensitive as the neuroblastoma neuro-2a assay, as the EC $_{50}$ values for STX and TTX were almost three orders of magnitude lower in the neuro-2a assay. Sensitivity in the low nanomolar range, as obtained in the neuro-2a assay, is required to detect these marine biotoxins in contaminated samples. Beating cardiomyocytes might also not be sensitive to neurotoxins with modes of action other than affecting ion channels or pumps as for example binding to specific neuronal receptors.

In summary, this is the first study proposing a cardiac model for neurotoxicity testing. Despite its limitations, the assessment of the beating arrest in murine embryonic stem cell-derived cardiomyocytes represents an interesting tool for the screening of compounds for their neurotoxic properties. Murine stem cell-derived cardiomyocytes provide a sensitive model for the detection of specific neurotoxins and the neuroblastoma neuro-2a assay appears to be a more promising cell-based assay for the screening of marine biotoxins. 


\section{References}

[1] ESAC, E. S. A. C., Statement on the Scientific Validity of the Embryonic Stem Cell Test (EST) - an In Vitro Test for Embryotoxicity. 2002.

[2] Bers, D. M., Cardiac excitation-contraction coupling. Nature 2002, 415, 198-205.

[3] Goodman, B. E., Channels active in the excitability of nerves and skeletal muscles across the neuromuscular junction: basic function and pathophysiology. Adv Physiol Educ 2008, 32, 127135.

[4] Chalfie, M., Neurosensory mechanotransduction. Nature reviews. Molecular cell biology 2009, 10, 44-52.

[5] Garthwaite, I., Keeping shellfish safe to eat: a brief review of shellfish toxins, and methods for their detection. Trends Food Sci Tech 2000, 11, 235-244.

[6] Malagoli, D., Casarini, L., Ottaviani, E., Algal toxin yessotoxin signalling pathways involve immunocyte mussel calcium channels. Cell Biol Int 2006, 30, 721-726.

[7] Twiner, M. J., Doucette, G. J., Rasky, A., Huang, X.-P., et al., Marine algal toxin azaspiracid is an open-state blocker of hERG potassium channels. Chem Res Toxicol 2012, 25, 1975-1984.

[8] Nicolas, J., Hendriksen, P. J., Gerssen, A., Bovee, T. F., Rietjens, I. M., Marine neurotoxins: state of the art, bottlenecks, and perspectives for mode of action based methods of detection in seafood. Molecular nutrition \& food research 2014, 58, 87-100.

[9] Paredes, I., Rietjens, I. M., Vieites, J. M., Cabado, A. G., Update of risk assessments of main marine biotoxins in the European Union. Toxicon : official journal of the International Society on Toxinology 2011, 58, 336-354.

[10] Balls, M., Straughan, D. W., The three Rs of Russell \& Burch and the testing of biological products. Developments in biological standardization 1996, 86, 11-18.

[11] European Commission, E., COMMISSION REGULATION (EU) No 15/2011. The Official Journal of the European Union 2011, L6/3_L6/6.

[12] Maltsev, V. A., Wobus, A. M., Rohwedel, J., Bader, M., Hescheler, J., Cardiomyocytes differentiated in vitro from embryonic stem cells developmentally express cardiac-specific genes and ionic currents. Circ Res 1994, 75, 233-244.

[13] Rasband, M. N., The axon initial segment and the maintenance of neuronal polarity. Nat Rev Neurosci 2010, 11, 552-562.

[14] Canete, E., Diogene, J., Comparative study of the use of neuroblastoma cells (Neuro-2a) and neuroblastomaxglioma hybrid cells (NG108-15) for the toxic effect quantification of marine toxins. Toxicon : official journal of the International Society on Toxinology 2008, 52, 541-550.

[15] Khalifa, M., Drolet, B., Daleau, P., Lefez, C., et al., Block of potassium currents in guinea pig ventricular myocytes and lengthening of cardiac repolarization in man by the histamine H1 receptor antagonist diphenhydramine. J Pharmacol Exp Ther 1999, 288, 858-865.

[16] Kuo, C. C., Huang, R. C., Lou, B. S., Inhibition of $\mathrm{Na}(+)$ current by diphenhydramine and other diphenyl compounds: molecular determinants of selective binding to the inactivated channels. Mol Pharmacol 2000, 57, 135-143.

[17] Tamura, K., Suzuki, Y., Koga, T., Akima, M., et al., Actions of CP-060S on veratridineinduced $\mathrm{Ca} 2+$ overload in cardiomyocytes and mechanical activities in vascular strips. European journal of pharmacology 1996, 312, 195-202.

[18] Yanagita, T., Kobayashi, H., Uezono, Y., Yokoo, H., et al., Destabilization of Na(v)1.7 sodium channel alpha-subunit mRNA by constitutive phosphorylation of extracellular signal- 
regulated kinase: negative regulation of steady-state level of cell surface functional sodium channels in adrenal chromaffin cells. Mol Pharmacol 2003, 63, 1125-1136.

[19] Anekonda, T. S., Quinn, J. F., Harris, C., Frahler, K., et al., L-type voltage-gated calcium channel blockade with isradipine as a therapeutic strategy for Alzheimer's disease. Neurobiology of disease 2011, 41, 62-70.

[20] Bergson, P., Lipkind, G., Lee, S. P., Duban, M. E., Hanck, D. A., Verapamil block of T-type calcium channels. Mol Pharmacol 2011, 79, 411-419.

[21] Keith, R. A., Mangano, T. J., DeFeo, P. A., Ernst, G. E., Warawa, E. J., Differential inhibition of neuronal calcium entry and $[3 \mathrm{H}]-\mathrm{D}$-aspartate release by the quaternary derivatives of verapamil and emopamil. Br J Pharmacol 1994, 113, 379-384.

[22] Ishii, T. M., Silvia, C., Hirschberg, B., Bond, C. T., et al., A human intermediate conductance calcium-activated potassium channel. Proceedings of the National Academy of Sciences of the United States of America 1997, 94, 11651-11656.

[23] Yang, B., Gribkoff, V. K., Pan, J., Damagnez, V., et al., Pharmacological activation and inhibition of Slack (Slo2.2) channels. Neuropharmacology 2006, 51, 896-906.

[24] Kodama, I., Kamiya, K., Toyama, J., Amiodarone: ionic and cellular mechanisms of action of the most promising class III agent. The American journal of cardiology 1999, 84, 20r-28r.

[25] Kagiava, A., Aligizaki, K., Katikou, P., Nikolaidis, G., Theophilidis, G., Assessing the neurotoxic effects of palytoxin and ouabain, both $\mathrm{Na}(+) / \mathrm{K}(+)$-ATPase inhibitors, on the myelinated sciatic nerve fibres of the mouse: an ex vivo electrophysiological study. Toxicon : official journal of the International Society on Toxinology 2012, 59, 416-426.

[26] Fuerstenwerth, H., On the differences between ouabain and digitalis glycosides. American journal of therapeutics 2014, 21, 35-42.

[27] Lee, C. H., Ruben, P. C., Interaction between voltage-gated sodium channels and the neurotoxin, tetrodotoxin. Channels (Austin) 2008, 2, 407-412.

[28] Huang, C.-J., Schild, L., Moczydlowski, E. G., Use-dependent block of the voltage-gated $\mathrm{Na}+$ channel by tetrodotoxin and saxitoxin: Effect of pore mutations that change ionic selectivity. J Gen Physiol 2012, 140, 435-454.

[29] Peters, A. K., Steemans, M., Hansen, E., Mesens, N., et al., Evaluation of the embryotoxic potency of compounds in a newly revised high throughput embryonic stem cell test. Toxicol Sci 2008, 105, 342-350.

[30] Aguilera, I. M., Vaughan, R. S., Calcium and the anaesthetist. Anaesthesia 2000, 55, 779790.

[31] Bergson, P., Lipkind, G., Lee, S. P., Duban, M.-E., Hanck, D. A., Verapamil block of Ttype calcium channels. Mol Pharmacol 2011, 79, 411-419.

[32] Lacinova, L., Hofmann, F., Isradipine interacts with the open state of the L-type calcium channel at high concentrations. Receptors Channels 1998, 6, 153-164.

[33] Ulbricht, W., Wagner, H. H., Schmidtmayer, J., Kinetics of TTX-STX block of sodium channels. Ann N Y Acad Sci 1986, 479, 68-83.

[34] Ashton, D., Willems, R., Marrannes, R., Janssen, P. A., Extracellular ions during veratridine-induced neurotoxicity in hippocampal slices: neuroprotective effects of flunarizine and tetrodotoxin. Brain Res 1990, 528, 212-222.

[35] Kogure, K., Tamplin, M. L., Simidu, U., Colwell, R. R., A tissue culture assay for tetrodotoxin, saxitoxin and related toxins. Toxicon : official journal of the International Society on Toxinology 1988, 26, 191-197. 
[36] Catterall, W. A., Goldin, A. L., Waxman, S. G., International Union of Pharmacology. XLVII. Nomenclature and structure-function relationships of voltage-gated sodium channels. Pharmacol Rev 2005, 57, 397-409.

[37] Nicolas, J., Hendriksen, P. J., van Kleef, R. G., de Groot, A., et al., Detection of marine neurotoxins in food safety testing using a multielectrode array. Molecular nutrition \& food research 2014, 58, 2369-2378.

[38] Natarajan, A., Stancescu, M., Dhir, V., Armstrong, C., et al., Patterned cardiomyocytes on microelectrode arrays as a functional, high information content drug screening platform. Biomaterials 2011, 32, 4267-4274. 